\title{
Influence of Thermal Annealing on the PdAl/Au Metal Stack Ohmic Contacts to p-AlGaN
}

\author{
Siva Pratap Reddy Mallem ${ }^{1}$, Woo-Hyun Ahn ${ }^{1}$, Jung-Hee Lee ${ }^{1, *}$ and Ki-Sik Im ${ }^{2}$ \\ 1 School of Electronics Engineering, Kyungpook National University, Daegu 41566, Korea; \\ drmspreddy@knu.ac.kr (S.P.R.M.); woohyun@knu.ac.kr (W.-H.A.) \\ 2 Advanced Material Research Center, Kumoh National Institute of Technology, Gumi 39177, Korea; \\ ksim@kumoh.ac.kr \\ * Correspondence: jlee@ee.knu.ac.kr; Tel.: +82-53-9408655
}

Received: 5 October 2020; Accepted: 25 November 2020; Published: 28 November 2020

check for updates

\begin{abstract}
In this study, a PdAl $(20 \mathrm{~nm}) / \mathrm{Au}(30 \mathrm{~nm})$ metal stack scheme is used for forming low-ohmic-resistance contact on Mg-doped $\left(1.5 \times 10^{17} \mathrm{~cm}^{-3}\right)$ p-type AlGaN at various annealing temperatures. Using a circular-transmission line model, the specific contact resistance $\left(\rho_{c}\right)$ of $\mathrm{PdAl} / \mathrm{Au} / \mathrm{p}-\mathrm{AlGaN}$ ohmic contact is determined via the current-voltage (I-V) characteristics. As-deposited contacts demonstrate non-linear behavior. However, the contact exhibits linear I-V characteristics with excellent ohmic contact of $\rho_{\mathrm{c}}=1.74 \times 10^{-4} \Omega \mathrm{cm}^{2}$, when annealed at $600{ }^{\circ} \mathrm{C}$ for 1 min in a $\mathrm{N}_{2}$ atmosphere. The $\mathrm{Ga}$ and $\mathrm{Al}$ vacancies created at the $\mathrm{PdAl} / \mathrm{Au}$ and p-AlGaN interfaces, which act as acceptors to increase the hole concentration at the interface. The out-diffusion of Ga as well as in-diffusion of $\mathrm{Pd}$ and $\mathrm{Au}$ to form interfacial chemical reactions at the interface is observed by $\mathrm{X}$-ray photoelectron spectroscopy (XPS) measurements. The phases of the Ga-Pd and Ga-Au phases are detected by X-ray diffraction (XRD) analysis. Morphological results show that the surface of the contact is reasonably smooth with the root-mean-square roughness of $2.89 \mathrm{~nm}$ despite annealing at $600{ }^{\circ} \mathrm{C}$. Based on the above experimental considerations, $\mathrm{PdAl} / \mathrm{Au} / \mathrm{p}-\mathrm{AlGaN}$ contact annealed at $600{ }^{\circ} \mathrm{C}$ is a suitable p-ohmic contact for the development of high-performance electronic devices.
\end{abstract}

Keywords: ohmic contact; p-AlGaN; PdAl metal-compound; Ga-phase; Core level binding energy shift

\section{Introduction}

The development of high-performance ohmic metal contacts on n/p-type AlGaN and n/p-type InGaN is increasing their potential for use in high-quality electro-optic devices, such as laser diodes, light-emitting diodes, and high-power/frequency high-electron-mobility transistors (HEMTs) [1-4]. Various metallization schemes, such as the use of $\mathrm{Ti} / \mathrm{Al}, \mathrm{Ti} / \mathrm{Ta} / \mathrm{Al}, \mathrm{Ta} / \mathrm{Ti} / \mathrm{Al}$, and Ti/Al/(Ti, Ni, Mo, Pd, and $\mathrm{Pt}$ )/Au, were used as ohmic contacts for n-type AlGaN [5-8]. For the aforementioned metallization schemes, the specific contact resistivity ( $\rho_{\mathrm{c}}$ ) obtained is low, ranging from $\sim 10^{-5}$ to $10^{-8} \Omega \mathrm{cm}^{2}[5-8]$, making them highly applicable to electronic devices, such as HEMTs and metal-semiconductor field-effect transistors MESFETs.

In particular, solid-state ultraviolet (UV) emitters for general lighting application require AlGaN layers with relatively high $\mathrm{Al}$ composition and hence the formation of ohmic contact on these layers, especially on $\mathrm{p}-\mathrm{AlGaN}$ layer, is much more difficult. Two main problems arise regarding the construction of good ohmic contact; (i) it is very difficult to grow a highly Mg-doped p-AlGaN, (ii) metal with work function higher than $\mathrm{p}-\mathrm{AlGaN}$ is rare. Due to these obstacles, only a few studies have been conducted so far [9-14]. For example, Blank et al. [9] found a potential barrier of approximately $2.3 \mathrm{~V}$ at the $\mathrm{Pd} / \mathrm{p}-\mathrm{Al}_{0.06} \mathrm{Ga}_{0.94} \mathrm{~N}$ contact after the thermal treatment. Jun et al. [10] applied a $\mathrm{Pd} / \mathrm{Au}$ 
$(35 / 100 \mathrm{~nm})$ metal scheme on p-type $\mathrm{Al}_{0.15} \mathrm{Ga}_{0.85} \mathrm{~N}$ with an acceptor concentration of $6 \times 10^{16} \mathrm{~cm}^{-3}$. They observed a linear current-voltage (I-V) curve after thermal annealing at $700{ }^{\circ} \mathrm{C}$ for $2 \mathrm{~min}$ in a $\mathrm{N}_{2}$ atmosphere. Kim et al. [11] demonstrated a low-resistance ohmic contact with a specific contact resistivity of $3.1 \times 10^{-4} \Omega \mathrm{cm}^{2}$ on the moderately doped p-AlGaN:Mg $\left(1.5 \times 10^{17} \mathrm{~cm}^{-3}\right)$ applying a $\mathrm{Pt} / \mathrm{Pd} / \mathrm{Au}(5 / 5 / 10 \mathrm{~nm})$ metal scheme and annealing at $600{ }^{\circ} \mathrm{C}$ for $1 \mathrm{~min}$ in a $\mathrm{N}_{2}$ atmosphere. Chary et al. [12] investigated the $\mathrm{Au} / \mathrm{Ni}$ layer to achieve an ohmic contact on p-type $\mathrm{GaN}$ and $\mathrm{AlGaN}$, which is annealed at $500{ }^{\circ} \mathrm{C}$ for $10 \mathrm{~min}$ in a $\mathrm{N}_{2}(90 \%)$ and $\mathrm{O}_{2}(10 \%)$ atmosphere, and found the lowest specific contact resistance $\left(\rho_{\mathrm{c}}\right)$ of $\sim 9.2 \times 10^{-6}$ and $1.8 \times 10^{-4} \Omega \mathrm{cm}^{2}$ for $\mathrm{p}-\mathrm{GaN}$ and $\mathrm{p}-\mathrm{AlGaN}$, respectively.

In the present study, we applied a $\mathrm{PdAl} / \mathrm{Au}$ metallization contact to p-type $\mathrm{AlGaN}$ to obtain reliable, low-ohmic-resistance contacts. A PdAl metallic alloy was used as the first layer because it has a heat of formation $(\Delta \mathrm{H}=-92 \mathrm{~kJ} / \mathrm{g}$ atom $)$ as well as low chemical reactivity with AlGaN. In addition, Au was used as a top coating film to protect the metal stack scheme from the ambient during annealing process. The main focus of this study was to investigate a reliable, low-ohmic-resistance contact of $\mathrm{PdAl} / \mathrm{Au}$ metallic stacks on p-type AlGaN, which was characterized before and after annealing by using the rapid thermal process (RTP). The mixing of the metallic alloyed contacts with the diffusion of $\mathrm{Ga}, \mathrm{N}, \mathrm{Pd}, \mathrm{Al}$, and $\mathrm{Au}$ from the $\mathrm{PdAl} / \mathrm{Au}$ metallic stacks and p-type $\mathrm{Al}_{0.15} \mathrm{Ga}_{0.85} \mathrm{~N}$ was observed via X-ray photoelectron spectroscopy (XPS) depth profiles. The interface products were determined by an $X$-ray diffractometer (XRD), and the roughness of the contact's surface was observed with a scanning probe microscopy (SPM) measurement.

\section{Materials and Methods}

The epitaxial structure studied in this work consisted of $1.5 \mu \mathrm{m}$-thick undoped GaN and $0.2 \mu \mathrm{m}$-thick $\mathrm{Mg}$-doped $\mathrm{Al}_{0.15} \mathrm{Ga}_{0.85} \mathrm{~N}$ layers with carrier concentration of $\sim 1.5 \times 10^{17} \mathrm{~cm}^{-3}$, which were sequentially grown on c-plane $\mathrm{Al}_{2} \mathrm{O}_{3}$ sapphire using a metal-organic chemical vapor deposition method. Prior to the metallization, the p-AlGaN films were ultrasonically cleaned with warm acetone, followed by isopropyl alcohol, for $5 \mathrm{~min}$ each. The films were then dipped into a buffer-oxide-etch solution for $10 \mathrm{~min}$ to remove the native surface oxides, and then dipped in deionized water. The patterns for the circular transmission line model (CTLM) were arranged on the p-AlGaN film with standard photolithography. A PdAl $(20 \mathrm{~nm}) / \mathrm{Au}(30 \mathrm{~nm})$ metallic scheme comprising a PdAl metal alloy as the first layer ( $90 \mathrm{wt} \%$ of $\mathrm{Pd} / 10 \mathrm{wt} \%$ of $\mathrm{Al}$ ) and $\mathrm{Au}$ as the second layer were deposited on the $\mathrm{p}-\mathrm{AlGaN}$ surface using the electron beam evaporation method followed by rapid thermal annealing (RTA) for $1 \mathrm{~min}$ at $400{ }^{\circ} \mathrm{C}, 500{ }^{\circ} \mathrm{C}, 600{ }^{\circ} \mathrm{C}$, and $700{ }^{\circ} \mathrm{C}$ for each sample in a $\mathrm{N}_{2}$ atmosphere. I-V curves were measured with a Keithley 4200 semiconductor parameter analyzer. XPS (Thermo Fisher Scientific Inc.) was performed to observe the in-/out-diffusion of the metal stacks and p-AlGaN before and after annealing using $\mathrm{Al} \mathrm{K} \alpha$ radiation $(1486.6 \mathrm{eV})$. We used the sputter with each rate $\sim 5.34 \mathrm{~nm} / \mathrm{min}$ for the characterization of atomic compositions of XPS depth profiles. XRD (PANalytical) with Cu $\mathrm{K} \alpha$ energy was used to illustrate the interface phases between the stack metals and p-AlGaN films. The morphological roughness of the contacts was analyzed using scanning probe microscopy (NX-20 SPM Controller, Park Systems) before and after annealing.

\section{Results and Discussion}

Figure 1a displays the I-V curves of the PdAl/Au metallization contacts on $\mathrm{p}-\mathrm{AlGaN}$ annealed at various temperatures, using CTLM with a spacing of $5 \mu \mathrm{m}$. A non-linear I-V behavior was observed in the as-deposited PdAl/Au/p-AlGaN ohmic contact, but the curve became linear when the contact was annealed at $400{ }^{\circ} \mathrm{C}$ and the slope of the curve increased as the annealing temperature increased up to $600^{\circ} \mathrm{C}$. When the temperature increased to $700^{\circ} \mathrm{C}$, however, the contact was apparently deteriorated showing non-linear I-V characteristics again. As shown in Figure $1 \mathrm{~b}$, the estimated $\rho_{\mathrm{c}}$ is $1.23 \times 10^{-2} \Omega \mathrm{cm}^{2}$ for the as-deposited film. For the samples annealed at $400,500,600$, and $700{ }^{\circ} \mathrm{C}$, the $\rho_{\mathrm{c}}$ values are $1.16 \times 10^{-3}, 5.27 \times 10^{-4}, 1.74 \times 10^{-4}$, and $1.01 \times 10^{-2} \Omega \mathrm{cm}^{2}$, respectively. The lowest $\rho_{\mathrm{c}}$ is achieved when the contact is annealed at $600{ }^{\circ} \mathrm{C}$, meaning that the best annealing temperature is 
$600^{\circ} \mathrm{C}$ for $\mathrm{PdAl} / \mathrm{Au}$ metallic contacts on $\mathrm{p}-\mathrm{AlGaN}$. It is also noticed that the $\rho_{\mathrm{c}}$ of $1.74 \times 10^{-4} \Omega \mathrm{cm}^{2}$ is the lowest value, even compared to those of various ohmic schemes obtained from other research groups as summarized in Table 1 [9-14]. The degradation of the contact annealed at $700{ }^{\circ} \mathrm{C}$ can be attributed to rough surface morphology at the ohmic contact, caused by the severe amalgamation between the $\mathrm{PdAl} / \mathrm{Au}$ metal and p-AlGaN may be due to the instability of p-AlGaN crystal structure [15].

(a)

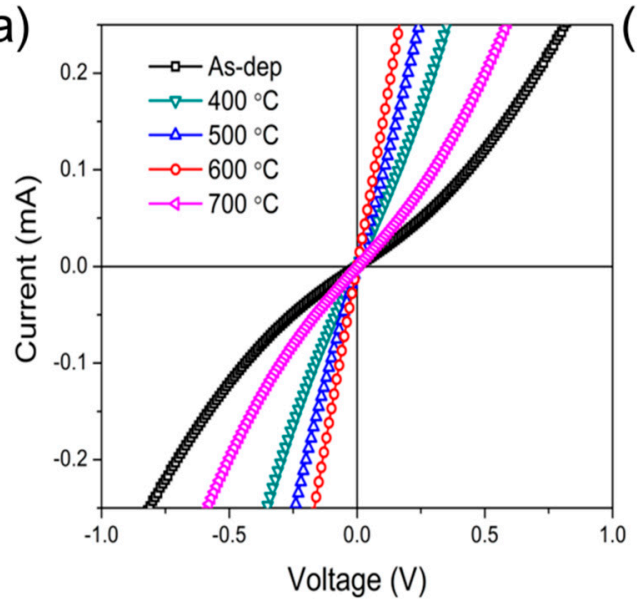

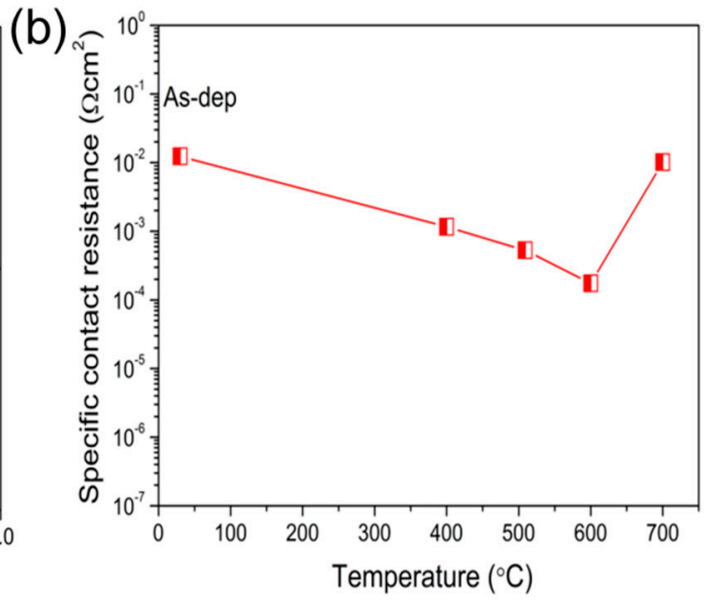

Figure 1. (a) Current-voltage (I-V) curves of the PdAl/Au metal stack contacts to $\mathrm{p}-\mathrm{AlGaN}$ as a function of annealing temperature. (b) Specific contact resistance $\left(\rho_{\mathrm{c}}\right)$ as a function of annealing temperature of $\mathrm{PdAl} / \mathrm{Au} / \mathrm{p}-\mathrm{AlGaN}$ ohmic contacts.

Table 1. Electrical characteristics of metal alloyed ohmic contact on p-AlGaN with various metallization schemes.

\begin{tabular}{cccccc}
\hline $\begin{array}{c}\text { Metallization } \\
\text { Scheme }\end{array}$ & $\begin{array}{c}\text { Annealing } \\
\text { Temperature } \\
\left({ }^{\circ} \mathbf{C}\right)\end{array}$ & $\begin{array}{c}\text { Anneal Time } \\
\text { (s) }\end{array}$ & Ambient & $\rho_{\mathrm{c}}\left(\boldsymbol{\Omega} \mathbf{c m}^{2}\right)$ & Ref \\
\hline $\mathrm{Pd}$ & 800 & 20 & $\mathrm{~N}_{2}$ & - & {$[9]$} \\
$\mathrm{Pd} / \mathrm{Au}$ & 700 & 120 & $\mathrm{~N}_{2}$ & - & {$[10]$} \\
$\mathrm{Pt} / \mathrm{Pd} / \mathrm{Au}$ & 600 & 60 & $\mathrm{~N}_{2}$ & $3.1 \times 10^{-4}$ & {$[11]$} \\
$\mathrm{Au} / \mathrm{Ni}$ & 500 & 600 & $\mathrm{~N}_{2}(90 \%)+\mathrm{O}_{2}(10 \%)$ & $1.8 \times 10^{-4}$ & {$[12]$} \\
$\mathrm{Ni} / \mathrm{Ag} / \mathrm{Ni}$ & 450 & - & - & $1.5 \times 10^{-2}$ & {$[13]$} \\
$\mathrm{Ni} / \mathrm{Au} / \mathrm{Ni} / \mathrm{Au}$ & $550+750$ & $180+30$ & $\mathrm{Air}+\mathrm{N}_{2}$ & - & {$[14]$} \\
$\mathrm{PdAl} / \mathrm{Au}$ & 600 & 60 & $\mathrm{~N}_{2}$ & $1.7 \times 10^{-4}$ & {$[$ This work] } \\
\hline
\end{tabular}

XRD examination was performed to study the interfacial phases formed between the $\mathrm{PdAl} / \mathrm{Au}$ metal alloyed layers and GaN films before and after annealing at $600{ }^{\circ} \mathrm{C}$. Figure 2a illustrates the XRD plot of the as-deposited contact. The diffraction plot reveals the distinctive substrate peaks of GaN (002) and $\mathrm{AlGaN}$ (002) were observed. In addition, superposition of peaks from pure metals $\mathrm{Al}(111), \mathrm{Pd}(111)$ and $\mathrm{Au}(111)$ were observed at $\sim 38.25^{\circ}$. Furthermore, a diffraction peak of $\mathrm{Au}(222)$ was observed at $\sim 81.85^{\circ}$. After annealing at $600{ }^{\circ} \mathrm{C}$ (Figure $2 \mathrm{~b}$ ), additional interfacial peaks were identified compared to the as-deposited contacts. These interfacial peaks were identified as $\mathrm{Ga}_{3} \mathrm{Pd}_{5}(020), \mathrm{Ga}_{2} \mathrm{Pd}_{5}(420)$, $\mathrm{Au}_{7} \mathrm{Ga}_{2}$ (205), and $\mathrm{Au}_{7} \mathrm{Ga}_{2}$ (226), which provide the $\mathrm{Ga}-\mathrm{Pd}$ and $\mathrm{Ga}-\mathrm{Au}$ metal-compound phases. 
(a)

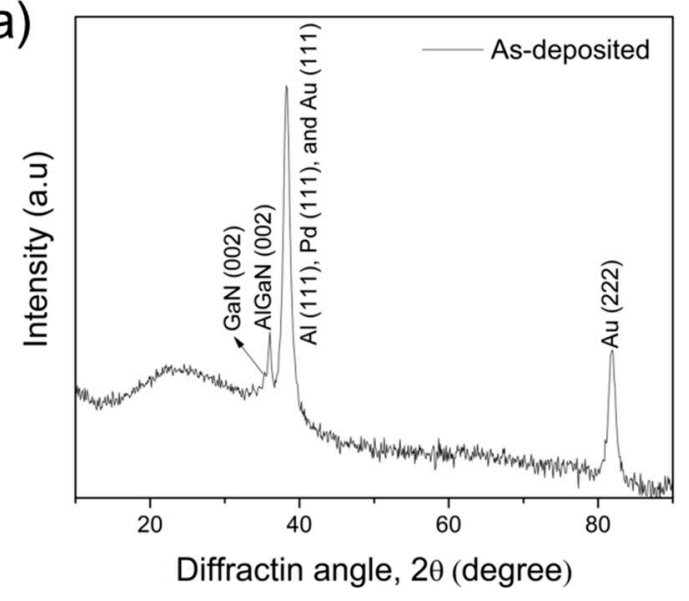

(b)

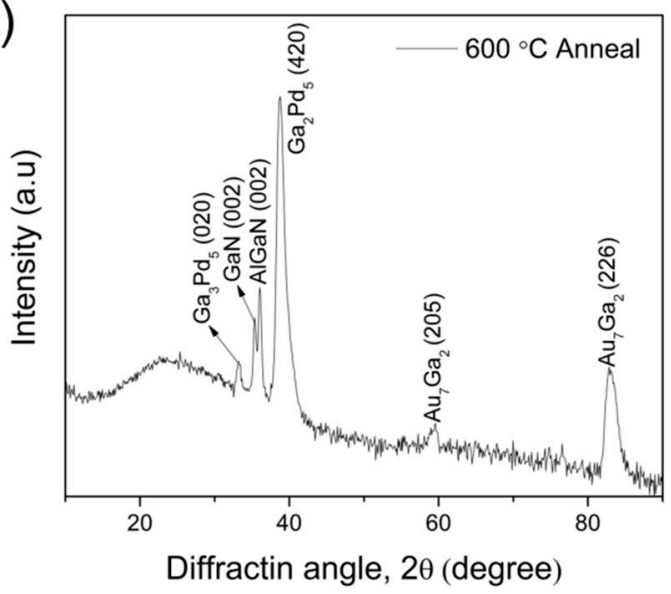

Figure 2. X-ray diffraction (XRD) plots of the PdAl/Au metal stack on p-AlGaN (a) as-deposited and (b) annealed at $600{ }^{\circ} \mathrm{C}$.

XPS analyses were conducted to elucidate the surface changes at the interface of the $\mathrm{PdAl} / \mathrm{Au}$ metal stack and p-AlGaN films. Figure 3 shows depth-profiling of the PdAl/Au metal stack before and after annealing at $600{ }^{\circ} \mathrm{C}$. The depth profiling of the as-deposited PdAl/Au metal stack (Figure 3a) shows that the transitions of $\mathrm{Pd}, \mathrm{Al}$, and $\mathrm{Au}$ films are clearly observable. When the metal stack is annealed at $600{ }^{\circ} \mathrm{C}$, as shown in Figure 3b, a clear variation is observed: compared to the as-deposited contacts, a large quantity of the $\mathrm{Ga}$ is out-diffused through the $\mathrm{Pd}$ and $\mathrm{Au}$ metals. This means that a large chemical reaction occurs between the PdAl metal alloy and Au, and Ga metallic content, which causes the interfacial phases of metallic $\mathrm{Ga}-\mathrm{Pd}$ and $\mathrm{Ga}-\mathrm{Au}$ to occur at the interface as confirmed from XRD results (Figure 2b). In addition, there is no clear evidence that the nitrogen content is out-diffused through the metal layers. This indicates that the chemically reacted layers making up the p-AlGaN surface can prevent the out-diffusion of the nitrogen content, which determines the performance of the p-ohmic metal contact. Thus, from the result obtained by XPS depth profiles we confirm that the $600^{\circ} \mathrm{C}$ sample shows that the enhancement in the I-V characteristics is due to formation of the Ga-related phases, causing the generation of Ga vacancies near the $\mathrm{p}$-AlGaN surface. Here, Ga vacancies are known to act as acceptors in p-AlGaN.

(a)

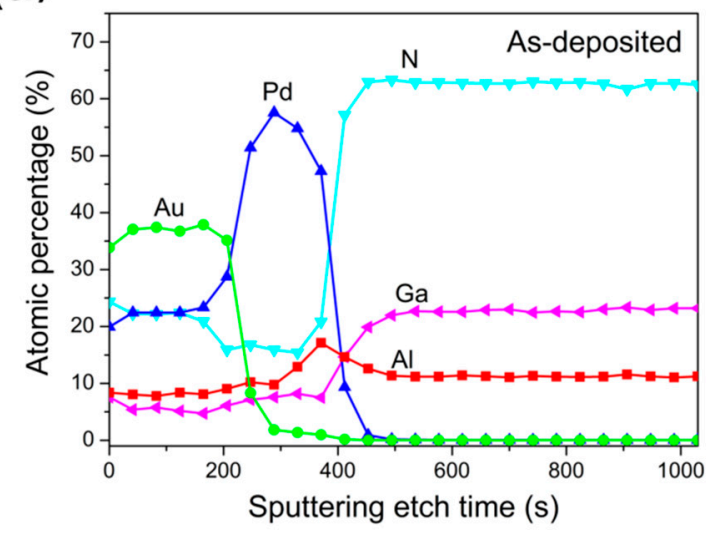

(b)

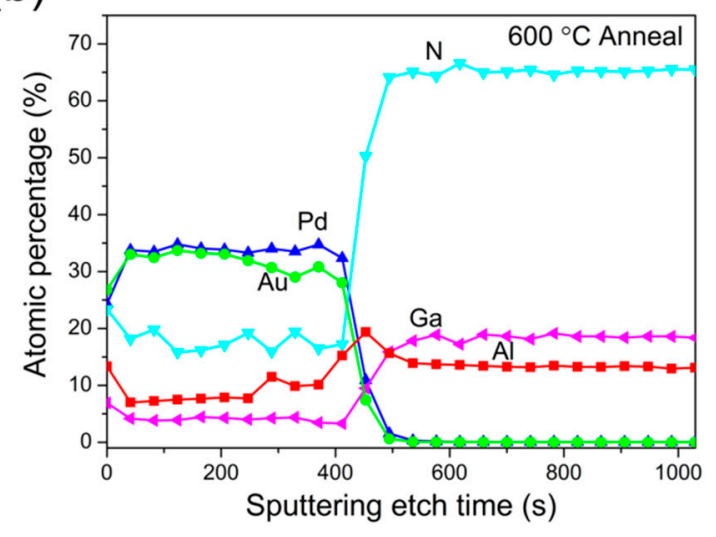

Figure 3. Depth-profiling of the $\mathrm{PdAl} / \mathrm{Au}$ metal stack on $\mathrm{p}-\mathrm{AlGaN}$ using $\mathrm{X}$-ray photoelectron spectroscopy (XPS): (a) as-deposited and (b) annealed at $600{ }^{\circ} \mathrm{C}$.

To further analyze the surface spectra of metallic Ga states, XPS measurements are performed before and after annealing at $600{ }^{\circ} \mathrm{C}$. Figure 4 a shows a characteristic wide spectrum of the XPS survey, where all core-level and energy features with electronic transitions of $\mathrm{Ga}, \mathrm{N}$, and $\mathrm{Al}$ are evident. 
As shown Figure 4b, the Ga-metallic $2 p$ surface-energy-level spectra are found on the interface of $\mathrm{PdAl} / \mathrm{Au}$ and p-type AlGaN before and after annealing at $600^{\circ} \mathrm{C}$. Unlike the as-deposited contact, the Ga-metallic $2 p$ surface energy level of the annealed contact $\left(600^{\circ} \mathrm{C}\right)$ shifts in the direction of the lower binding energy side. The $\sim 0.36 \mathrm{eV}$ binding energy shift of the metallic Ga $2 p$ XPS peak is observed compared to the as-deposited contact. This behavior is related to the fact that the surface Fermi energy level moves toward the valence band side [16]. The reason for the reduction in energy band bending (i.e., the bending of the surface Fermi energy level toward the valence band side) in the $600{ }^{\circ} \mathrm{C}$ annealed contacts could be due to reduction in the Schottky barrier height between the PdAl/Au metals and $\mathrm{p}$-AlGaN films, which results in a low $\rho_{\mathrm{c}}$ value. This surface Fermi energy-level shift can be initiated to increase Ga vacancies in $\mathrm{p}-\mathrm{AlGaN}$, which act like acceptors to enhance the acceptor concentration near the $\mathrm{p}-\mathrm{AlGaN}$ surface of the annealed contact. A similar influence of annealing was observed in the Pt/Pd/Au and Pd/Au contacts on p-AlGaN [10,11].

(a)

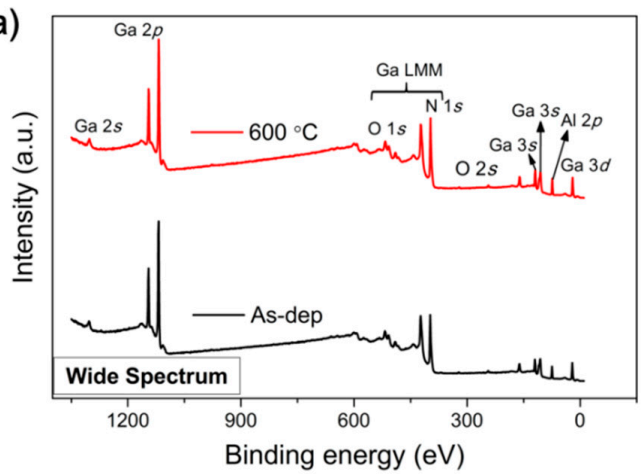

(b)

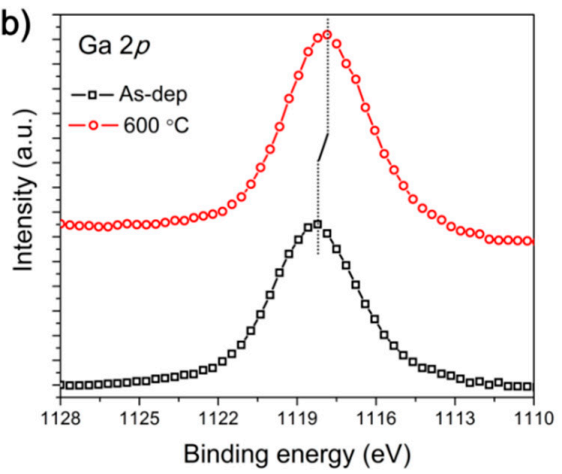

Figure 4. (a) Wide survey spectrum and (b) Ga $2 p$ energy level of XPS for the PdAl/Au metal stack on $\mathrm{p}$-AlGaN before and after annealing at $600^{\circ} \mathrm{C}$.

To explain the annealing behavior and understand the mechanism of ohmic contact formation on p-AlGaN, the samples were morphologically characterized using SPM measurements. Figure 5 shows the morphological images of the samples before and after annealing at $600^{\circ} \mathrm{C}$, obtained on a $5 \mu \mathrm{m} \times 5 \mu \mathrm{m}$ (scanned image size). Figure 5a illustrates that the morphological image of the as-deposited contact is a very rough surface, with a root-mean-square (RMS) roughness of $13.53 \mathrm{~nm}$. When the ohmic contact is annealed at $600{ }^{\circ} \mathrm{C}$ (Figure $5 \mathrm{~b}$ ), its surface roughness decreases, demonstrating an RMS roughness of 2.89 $\mathrm{nm}$ compared to the as-deposited contact. These results indicate that, overall, the surface morphology of $\mathrm{PdAl} / \mathrm{Au}$ contacts on $\mathrm{p}-\mathrm{AlGaN}$ is fairly smooth despite the annealing conducted at $600{ }^{\circ} \mathrm{C}$.

(a) ${ }_{n m}$

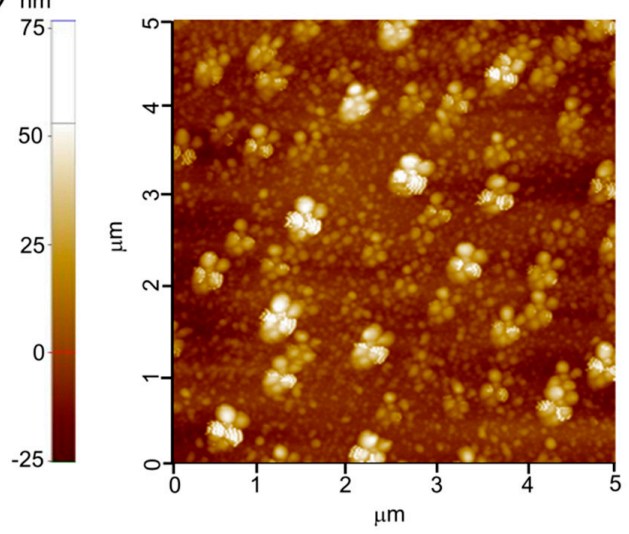

(b) ${ }_{\mathrm{nm}}$

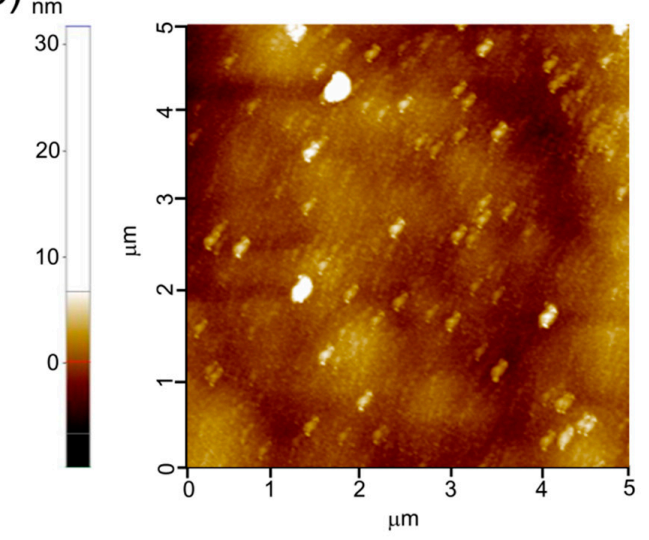

Figure 5. Surface morphologies of the PdAl/Au metal stack on p-type AlGaN: (a) as-deposited, and (b) annealed at $600{ }^{\circ} \mathrm{C}$. 


\section{Conclusions}

We experimentally studied the PdAl/Au metal stack on Mg-doped p-AlGaN for fabricating high-performance, highly reliable ohmic contacts. The results revealed that a high-quality ohmic contact was achieved with annealing compared to as-deposited contact. The contact resistance was $1.74 \times 10^{-4} \Omega \mathrm{cm}^{2}$ when annealed at $600{ }^{\circ} \mathrm{C}$ for $1 \mathrm{~min}$ in a high-purity $\mathrm{N}_{2}$ atmosphere. XPS and XRD systematic analyses showed that $\mathrm{Ga}-\mathrm{Pd}$ and $\mathrm{Ga}-\mathrm{Au}$ phases created when the contacts were annealed at $600{ }^{\circ} \mathrm{C}$ causing the generation of Ga vacancies near the p-AlGaN surface were responsible for the enhanced acceptor (hole) concentration near the p-AlGaN surface. The SPM results specified that the RMS roughness of the metal contact was reasonably low for $600^{\circ} \mathrm{C}$ annealed contacts. Annealing gives potential benefits of the presence of low-resistance p-ohmic contacts between the $\mathrm{PdAl} / \mathrm{Au}$ metal stack and $\mathrm{p}-\mathrm{AlGaN}$ including improved performance.

Author Contributions: Conceptualization, S.P.R.M.; Measurements: S.P.R.M. and W.-H.A., K.-S.I.; Characteristics, S.P.R.M. and W.-H.A., K.-S.I.; Analysis: S.P.R.M., J.-H.L.; Writing, S.P.R.M., J.-H.L.; Supervision, J.-H.L.; funding acquisition, S.P.R.M., J.-H.L. All authors have read and agreed to the published version of the manuscript.

Funding: This research received no external funding.

Acknowledgments: This work was supported by the National Research Foundation of Korea funded by the Ministry of Science, ICT, and Fusion Research (NRF-2018R1D1A1B07040603) and BK21 Plus funded by the Ministry of Education (21A20131600011).

Conflicts of Interest: The authors declare no conflict of interest.

\section{References}

1. Aoki, Y.; Kuwabara, M.; Yamashita, Y.; Takagi, Y.; Sugiyama, A.; Yoshida, H. A 350-nm-Band GaN/AlGaN Multiple-Quantum-Well Laser Diode on Bulk GaN. Appl. Phys. Lett. 2015, 107, 151103. [CrossRef]

2. Mallem, S.P.R.; Park, H.; Kim, S.-M.; Jang, S.-H.; Jang, J.-S. High-Performance Light-Emitting Diodes Using Hierarchical M-Plane GaN Nano-Prism Light Extractors. J. Mater. Chem. C 2015, 3, 8873-8880.

3. Mallem, S.P.R.; Park, W.-S.; Im, K.-S.; Lee, J.-H. Dual-Surface Modification of AlGaN/GaN HEMTs Using TMAH and Piranha Solutions for Enhancing Current and 1/f-Noise Characteristics. J. Electron Dev. Soc. 2018, 6, 791-796. [CrossRef]

4. Doundoulakis, G.; Adikimennakis, A.; Stavrinidis, A.; Tsagaraki, K.; Androulidaki, M.; Iacovella, F.; Deligeorgis, G.; Konstantinidis, G.; Georgakilas, A. Nanofabrication of Normally-Off GaN Vertical Nanowire MESFETs. Nanotechnlogy 2019, 30, 285304. [CrossRef] [PubMed]

5. Rauvimov, S.; Liliental-Weber, Z.; Washburn, J.; Qiao, D.; Lau, S.S.; Chu, P.K. Microstructure of Ti/Al Ohmic Contacts for N-AlGaN. Appl. Phys. Lett. 1998, 73, 2582-2584. [CrossRef]

6. Lim, S.-H.; Washburn, J.; Liliental-Weber, Z.; Qiao, D. Microstructural Evidence on Electrical Properties of $\mathrm{Ta} / \mathrm{Ti} / \mathrm{Al}$ and Ti/Ta/Al Ohmic Contacts to N-AlGaN/GAN. Appl. Phys. Lett. 2001, 78, 3797-3799. [CrossRef]

7. Bardwell, J.A.; Sproule, G.I.; Liu, Y.; Tang, H.; Webb, J.B.; Fraser, J.; Marshall, P. Comparison of Two Different Ti/Al/Ti/Au Ohmic Metallization Schemes for AlGaN/GaN. J. Vac. Sci. Technol. 2002, 20, 1444-1447. [CrossRef]

8. Kumar, V.; Zhou, L.; Selvanathan, D.; Adesida, I. Thermally-Stable Low-Resistance Ti/Al/Mo/Au Multilayer Ohmic Contacts on N-GaN. J. Appl. Phys. 2002, 92, 1712-1714. [CrossRef]

9. Blank, T.V.; Goldberg, Y.A.; Kalinina, E.V.; Konstantinov, O.V.; Nikolaev, A.E.; Fomin, A.V.; Cherenkov, A.E. Mechanism of the Current Flow in Pd-(Heavily Doped P- $\left.\mathrm{Al}_{\mathrm{x}} \mathrm{Ga}_{1-\mathrm{x}} \mathrm{N}\right)$ Ohmic Contact. Semiconductors 2001, 35, 550-553. [CrossRef]

10. Jun, B.-H.; Hirayama, H.; Aoyagi, Y. Effect of Thermal Annealing on the Pd/Au Contact to P-Type Al0.15Ga0.85N. Jpn. J. Appl. Phys. 2002, 41, 581-582. [CrossRef]

11. Kim, H.-K.; Seong, T.-Y.; Adesida, I.; Tang, C.W.; Lau, K.M. Low-Resistance Pt/Pd/Au Ohmic Contacts to P-Type AlGaN. Appl. Phys. Lett. 2004, 84, 1710-1712. [CrossRef]

12. Chary, I.; Borisov, B.; Kuryatkov, V.; Kudryavtsev, Y.; Asomoza, R.; Nikishin, S.; Holtz, M. Low Resistance Ohmic Contacts to P-Type GaN and AlGaN. Mater. Res. Soc. Symp. Proc. 2009, 1108, 1108-A09-30. 
13. Passow, T.; Gutt, R.; Maier, M.; Pletschen, W.; Kunzer, M.; Schmidt, R.; Wiegert, J.; Luick, D.; Liu, S.; Kohler, K.; et al. Ni/Ag as Low Resistive Ohmic Contact to P-Type AlGaN for UV LEDs. Prof. SPIE 2015, 7617, 76171I-1-76171I-7. [CrossRef]

14. Hu, Z.F.; Li, X.Y.; Zhang, Y. Characteristics of Ni/Au/Ni/Au Ohmic Contact in a P-AlGaN/GaN Semiconductor. IOP Conf. Ser. Mater. Sci. Eng. 2020, 770, 012018. [CrossRef]

15. Reddy, V.R. Study of the Electrical, Structural and Surface Morphological Characteristics of Pt/Re/Au Ohmic Contacts on P-Type GaN. Mater. Chem. Phys. 2005, 93, 286-290. [CrossRef]

16. Sun, J.; Rickert, K.A.; Redwing, J.M.; Ellis, A.B.; Himpsel, F.J.; Kuech, T.F. p-GaN Surface Treatments for Metal Contacts. Appl. Phys. Lett. 2000, 76, 415-417. [CrossRef]

Publisher's Note: MDPI stays neutral with regard to jurisdictional claims in published maps and institutional affiliations.

(C) 2020 by the authors. Licensee MDPI, Basel, Switzerland. This article is an open access article distributed under the terms and conditions of the Creative Commons Attribution (CC BY) license (http://creativecommons.org/licenses/by/4.0/). 